\title{
Studies on antivenom activity of Andrographis paniculata and Aristolochia indica plant extracts against Daboia russelli venom by in vivo and in vitro methods S. Meenatchisundaram ${ }^{1}$, G. Parameswari ${ }^{2}$ and A. Michael ${ }^{2}$
${ }^{1}$ Dept. of Microbiol., Nehru Arts \& Science College, ${ }^{2}$ PSG College of Arts and Science, Coimbatore, India. drmscbe@gmail.com
}

Abstract: Methanolic extracts of Andrographis paniculata and Aristolochia indica plants were tested for antivenom activity against Daboia russelli venom. Both plant extracts effectively neutralized the $D$. russelli venom induced lethal activity. About $0.15 \mathrm{mg}$ of $A$. paniculata and 0.14 $\mathrm{mg}$ of $A$. indica plant extracts were able to completely neutralize the lethal activity of $2 \mathrm{LD}_{50}$ of $D$. russelli venom. Various pharmacological activities including edema, haemorrhagic, coagulant, fibrinolytic and phospholipase activities were studied and these pharmacological activities were significantly neutralized by both the plant extracts. The above observations confirmed that $A$. paniculata and $A$. indica plant extracts possess potent snake venom neutralizing capacity and could potentially be used for therapeutic purposes in case of snakebite envenomation.

Keywords: AntiVenom, plant extracts, snake bite. Introduction

Snakebite is a major health hazard that leads to high mortality rate especially in India. The common poisonous snakes found in India are Cobra (Naja naja), Krait (Bangarus Caeruleus), Russell's viper (Daboia russelli) and Saw Scaled Viper (Echis Carinatus) (Bawaskar, 2004). About 35,000 to 50,000 people die of snakebite every year in India. Vipera russellii and Naja kaouthia are the common snakes found throughout India and a large number of deaths occur due to envenomation by these snakes (Alam \& Gomes, 2003). Antivenom immunotherapy is the only specific treatment against snake venom envenomation. There are various side effects of antivenom such as anaphylactic shock, pyrogen reaction and serum sickness. Most of these symptoms may be due to the action of high concentrations of nonimmunoglobulin proteins present in commercially available hyper immune antivenom (Maya Devi et al., 2002). Over the years many attempts have been made for the development of snake venom antagonists from plants sources. Several medicinal plants, which appear in old drug recipes or which have been passed on by oral tradition, are believed to be snakebite antidotes and are recommended for the treatment of snakebite (Alam \& Gomes, 2003). Some of these plant extracts has shown antivenom property on land snakes and their possible mechanism of action have been suggested. In almost any part of the world, where venomous snakes occur, numerous plant species are used as folk medicine to treat snakebite. The present investigation explored the $D$. russelli venom neutralizing activity of Andrographis paniculata and Aristolochia indica plant extracts by in vivo and in vitro methods.

Materials and methods

Venom and experimental animals

Research article

Clndian Society for Education and Environment (iSee)
The freeze-dried snake venom powder of Daboia russelli was obtained from Irula's Snake Catchers Industrial Co-operative Society Limited, Chennai and was stored at $4^{\circ} \mathrm{C}$. Male inbreed Swiss albino mice 18-20 g were used for efficacy studies. Institutional Animal Ethics Committee clearance at Institute of Vector Control and Zoonooses, Hosur, was obtained to conduct the experiment.

Medicinal plants and preparation of extracts

Andrographis paniculata and Aristolochia indica plants were obtained from RVS Ayurveda College, Sulur. The whole plant material was dried in shade and the airdried plant was ground and extracted first by refluxing with petroleum ether $\left(50-60^{\circ} \mathrm{C}\right.$, for $\left.72 \mathrm{~h}\right)$ and then with methanol $\left(60-80^{\circ} \mathrm{C}\right.$ for $\left.72 \mathrm{~h}\right)$. The methanol extract was concentrated in vaccuo and kept in a desiccator at room temperature for further use. Before use, it was dissolved in saline and centrifuged at $2000 \mathrm{rpm}$ for $10 \mathrm{~min}$ at room temperature. The supernatant was used for further investigation and kept at $4^{\circ} \mathrm{C}$. The plant extracts were expressed in terms of dry weight.

In vivo assessment of venom toxicity and anti-venom effect of plant extracts

Lethal toxicity: The median lethal dose $\left(\mathrm{LD}_{50}\right)$ of $D$. russelli venom was determined according to the method developed by Theakston and Reid 1983. Various doses of venom in $0.2 \mathrm{ml}$ of physiological saline was injected into the tail vein of mice, using groups of 3-5 mice for each venom dose. The $L_{50}$ was calculated with the confidence limit at $50 \%$ probability by the analysis of deaths occurring within $24 \mathrm{~h}$ of venom injection. The antilethal potentials of $A$. paniculata and $A$. indica plant extracts were determined against $2 \mathrm{LD}_{50}$ of $D$. russelli venom. Various amount of plant extracts $(\mu \mathrm{l})$ were mixed with $2 \mathrm{LD}_{50}$ of venom sample and incubated at $37^{\circ} \mathrm{C}$ for 30 minutes and then injected intravenously into mice. 3-5 mice were used at each antivenom dose. Control mice received same amount of venom without antivenom (plant extracts). The median Effective Dose $\left(E D_{50}\right)$ calculated from the number of deaths within $24 \mathrm{~h}$ of injection of the venom/antivenom mixture. $E_{50}$ was expressed as $\mu \mathrm{l}$ antivenom/mouse and calculated by probit analysis.

Edema- forming Activity: The minimum edema-forming dose (MED) of $D$. russelli venom was determined by the method of Lomonte et al. (1993) and Camey et al. (2002). MED was defined as the least amount of venom which when injected subcutaneously into mice footpad results in $30 \%$ edema with in 6 hours of venom injection. The thickness of each footpad was measured every $30 \mathrm{~min}$ after venom injection with a low-pressure spring caliper (Rojas et al., 2005). The ability of both plant extracts in
"Plant extracts as antivenom" http://www.indjst.org
Meenatchisundaram et al. Indian J.Sci.Technol. 
neutralizing the edema-forming activity were carried out by pre-incubating the constant amount of venom and various dilutions $A$. paniculata and $A$. indica plant extracts for 30 minutes at $37^{\circ} \mathrm{C}$. Mice were injected subcutaneously in the right footpad with $50 \mu \mathrm{l}$ of the mixtures, containing venom/plant extracts, whereas the left footpad received $50 \mu \mathrm{l}$ of PBS alone. Control mice were injected with venom in the right footpad and $50 \mu \mathrm{l}$ of PBS in the left footpad. 1 hour after injection edema was evaluated as described by Yamakawa et al. (1976). Edema was expressed as the percentage increase in thickness of the right footpad compared to the right footpad of the control mice.

Haemorrhagic activity: The minimum haemorrhagic dose (MHD) of Daboia russelli venom was determined by the method described by Theakston and Reid, 1983. The minimum haemorrhagic dose was defined as the least amount of venom which when injected intradermaly (i.d.) into mice results in a haemorrhagic lesion of $10 \mathrm{~mm}$ diameter in 24 hours. Neutralization of the haemorrhagic activity was estimated by mixing a fixed amount of venom with different amounts plant extracts. The plant extractvenom mixture was incubated at $37^{\circ} \mathrm{C}$ for $1 \mathrm{~h}$ and $0.1 \mathrm{ml}$ of the mixture was injected intradermaly into mice. The haemorrhagic lesion was estimated after $24 \mathrm{~h}$.

Defibrinogenating activity: The minimum defibrinogenating dose (MDD) of Daboia russellivenom is defined as the minimum amount of venom which when injected i.v. into mice causes incoagulable blood $1 \mathrm{~h}$ later (Theakston \& Reid, 1983). Neutralization of this activity was estimated by mixing different amount of venom with fixed amounts of plant extract, incubating at $37^{\circ} \mathrm{C}$ for $1 \mathrm{~h}$, and centrifuging. The supernatant was injected i.v. into mice and the nature of the blood observed after $1 \mathrm{~h}$.

In vitro assessment of venom toxicity and anti-venom effect of plant extracts

Phospholipase activity. Phospholipase A2 activity was measured using an indirect hemolytic assay on agaroseerythrocyte-egg yolk gel plate by the methods described by Gutierrez et al., 1988. Increasing doses of Daboia russelli venom $(\mu \mathrm{g})$ were added to $3 \mathrm{~mm}$ wells in agarose gels $(0.8 \%$ in PBS, $\mathrm{pH} 8.1)$ containing $1.2 \%$ sheep erythrocytes, $1.2 \%$ egg yolk as a source of lecithin and $10 \mathrm{mM} \mathrm{CaCl}$. Slides were incubated at $37^{\circ} \mathrm{C}$ overnight and the diameters of the hemolytic halos were measured. Control wells contained $15 \mu \mathrm{l}$ of saline. The minimum indirect hemolytic dose (MIHD) corresponds to a dosage of venom, which produced a hemolytic halo of $11 \mathrm{~mm}$ diameter. The efficacy of antivenom (plant extracts) in neutralizing the phospholipase activity was determined by mixing constant amount of venom $(\mu \mathrm{g})$ with various amount of plant extracts $(\mu \mathrm{l})$ and incubated for 30 minutes at $37^{\circ} \mathrm{C}$. Then, aliquots of $10 \mu \mathrm{l}$ of mixtures were added to wells in agarose-egg yolk-

Table 1. Neutralization of D. russelli venom induced lethality by plant extracts

\begin{tabular}{|c|c|c|}
\hline Plant extracts & $\begin{array}{c}\text { Dose of } \\
\text { D. russelli } \\
\text { venom }(\mu \mathrm{g})\end{array}$ & $\begin{array}{c}\text { Neutralization of } \\
\text { venom by plant } \\
\text { extracts (ED } \text { En in } \mathrm{mg})\end{array}$ \\
\hline A. paniculata & $16\left(2 \mathrm{LD}_{50}\right)$ & $0.15 \mathrm{mg}$ \\
\hline$A$. indica & $16\left(2 \mathrm{LD}_{50}\right)$ & $0.14 \mathrm{mg}$ \\
\hline
\end{tabular}

"Plant extracts as antivenom" http://www.indjst.org
Vol.2 No 4 (Mar. 2009)

ISSN: 0974- 6846 sheep erythrocyte gels. Control samples contain venom without plant extracts. Plates were incubated at $37^{\circ} \mathrm{C}$ for $20 \mathrm{~h}$. Neutralization was expressed as the ratio of $\mathrm{mg}$ antibodies $/ \mathrm{mg}$ venom which could reduce the diameter of the hemolytic halo by $50 \%$ when compared to the effect induced by venom alone.

Procoagulant activity: Procoagulant activity was assayed according to the method described by Theakston and Reid, 1983 as modified by Laing et al., 1992. Various amounts of venom dissolved in $100 \mu$ PBS (pH 7.2) was added to human citrated plasma at $37^{\circ} \mathrm{C}$. Coagulation time was recorded and the minimum coagulant dose (MCD) was determined as the venom dose, which induced clotting of plasma within 60 seconds. Plasma incubated with PBS alone served as control. In neutralization assays constant amount of venom was mixed with various dilutions of plant extracts. The mixtures were incubated for 30 minutes at $37^{\circ} \mathrm{C}$. Then $0.1 \mathrm{ml}$ of mixture was added to $0.3 \mathrm{ml}$ of citrated plasma and the clotting times recorded. In control tubes plasma was incubated with either venom alone or plant extracts alone. Neutralization was expressed as effective dose (ED), defined as the ratio $\mu \mathrm{l}$ antivenom (plant extracts) $/ \mathrm{mg}$ venom at which the clotting time increased three times when compared with clotting time of plasma incubated with two MCD of venom alone.

Fibrinolytic activity: A modified plaque assay was used (Rojas et al., 1987). The minimum fibrinolytic concentration was defined as the concentration of venom that induced a fibrinolytic halo of $10 \mathrm{~mm}$ diameter. Neutralization experiments were performed by incubating a constant amount of venom with various amounts of plant extracts at $37^{\circ} \mathrm{C}$ for $1 \mathrm{~h}$. After incubation, the mixture was applied to the wells in the plaque. After $18 \mathrm{~h}$ of incubation at $37^{\circ} \mathrm{C}$, fibrinolytic halos were measured. Statistical Analysis

Statistical evaluation was performed using XL Stat 2007 and SPSS 10 software. $P<0.005$ was considered statistically significant.

Results

The antivenom potential of $A$. paniculata and $A$. indica plant extracts were tested against Daboia russelli venom using in vivo and in vitro methods. The lethal toxicity $\left(\mathrm{LD}_{50}\right)$ of $D$. russelli venom was assessed using Balb/c strain mice. About $8 \mu \mathrm{g}$ of $D$. russelli venom was found to be $L D_{50}$ for $18 \mathrm{~g}$ of mice. The neutralization of lethality was done by mixing constant amount of venom $\left(2 \mathrm{LD}_{50}\right)$ with various dilutions of $A$. paniculata and $A$. indica plant extracts and incubated at $37^{\circ} \mathrm{C}$ for 30 minutes prior to injection. We found that $0.15 \mathrm{mg}$ of $A$. paniculata and $0.14 \mathrm{mg}$ of $A$. indica plant extracts were able to completely neutralize the lethal activity of $2 \mathrm{LD}_{50}$ of $D$. russelli venom (Table 1, Fig. 1).

In edema forming activity, mice immunized with Daboia

Meenatchisundaram et al. Indian J.Sci.Technol. 
russellivenoms showed an increase in footpad thickness. About $4 \mu \mathrm{g}$ of Russell's viper venom induced edema formation within $3 \mathrm{~h}$ which is considered as $100 \%$ activity. The edema was reduced up to $30 \%$ when $2.7 \mathrm{mg}$ of plant extracts per $\mathrm{mg}$ venom was given. No further reduction in the percentage of edema was observed even when there was an increase in antivenom dose (Fig. 2).

In the case of hemorrhagic activity, Russell's viper venom did not produced any visible hemorrhagic spot. In phospholipase activity $\left(\mathrm{PLA}_{2}\right), \quad D$. russelli venom able to produce hemolytic haloes in agarose-sheep erythrocytes gels. About $10 \mu \mathrm{g}$ of Russell's viper venom produced $11 \mathrm{~mm}$ diameter hemolytic halo, which is considered to be $1 \mathrm{U}$ $(\mathrm{U} / 10 \mu \mathrm{g})$. This shows that $D$. russelli venoms have the enzymes $\left(\mathrm{PLA}_{2}\right)$ that has the ability to lyse sheep RBC's. Both plant extracts were capable of inhibiting $\mathrm{PLA}_{2}$ dependent hemolysis of sheep RBC's induced by $D$. russelli venom in a dose dependent manner. We found that that $0.13 \mathrm{mg}$ of $A$. paniculata fibrinolytic activity (modified plaque assay) induced by $D$. russellivenom.

\section{Discussion}

Snakebite is a major health hazard that leads to high mortality rate especially in India. Vipera russelli and Naja kaouthia are the common snakes found throughout India

and $0.11 \mathrm{mg}$ of $A$. indica plant extracts were able to completely inhibit $\mathrm{PLA}_{2}$ dependent hemolysis of sheep RBC's induced by $D$. russelli venom (Table 2). The minimum coagulant dose (MCD) was determined as the venom dose inducing clotting of plasma in $60 \mathrm{~s}$. About $120 \mu \mathrm{g}$ of Russell's viper venom clotted human citrated plasma within 60s. In the neutralization assay, the absence of clot formation shows the neutralizing ability of both plant extracts. We found that $1.8 \mathrm{mg}$ of $A$. paniculata and 1.6 $\mathrm{mg}$ of $A$. indica plant extracts were able to completely neutralize coagulant activity. High dose of venom caused
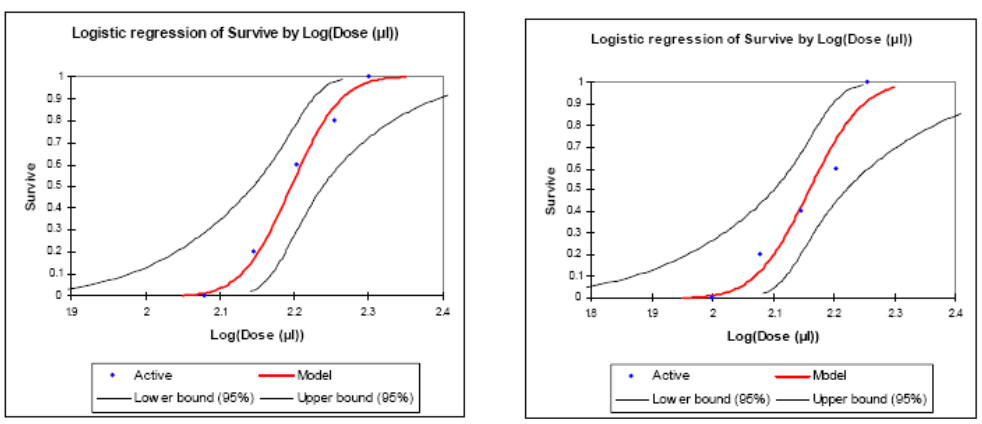

Fig 1 - Dose response curve for Neutralization of Lethality by a) Andrographis paniculata and b) Aristolochia indica Plant extracts against Daboia russelli venom in experiments involving preincubation of venom $\left(2 \times \mathrm{LD}_{50}\right)$ and various concentrations of antivenoms (Plant Extracts). The median effective dose for Daboia russelli venom was $157.0 \mu 1(139.45$ - 173.16) for Andrographis paniculata and 144.26 $\mu 1$ (126.06-165.69) for Aristolochia indica Plant extracts

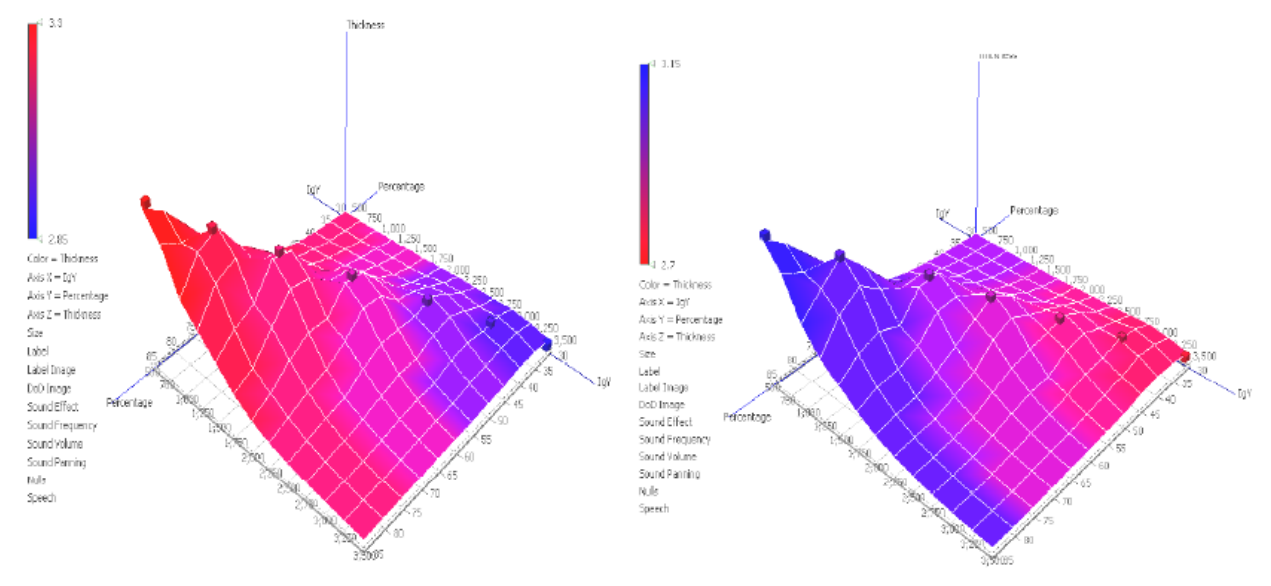

rapid clotting that required very high dose of antivenom to neutralize. $A$. paniculata and $A$. indica plant extracts were effectively antagonised the Russell's viper venominduced defibrinogenating activity. The effective dose were found to be $1.3 \mathrm{mg}$ for $A$. paniculata and $1.1 \mathrm{mg}$ for $A$. indica plant extracts. The viper venom-induced fibrinolytic effect was effectively antagonized by the plant extracts ( $A$. paniculata and $A$. indica). The ED50 of $A$. paniculata and $A$. indica were found to be 0.6 and 0.5 $\mathrm{mg}$, respectively. Both plant extracts were capable of inhibiting fibrinolytic activity induced by $D$. russelli venom. We found that that $0.14 \mathrm{mg}$ of $A$. paniculata and $0.11 \mathrm{mg}$ of $A$. indica plant extracts were able to completely inhibit

Research article

CIndian Society for Education and Environment (iSee)
"Plant extracts as antivenom" http://www.indjst.org and a large number of deaths occur due to envenomation by these snakes. Antisnake venom remains the specific antidote for snake venom poisoning. This antisnake venom is usually derived from horse sera. They contain horse immunoglobulins, which frequently caused complement mediated side effects, and other proteins that cause serum sickness and occasionally, anaphylactic shock. Although, use of plants against the effects of snakes bite has been long recognized, more scientific attention has been given since last 20 years (Santosh et al., 2004). Many Indian medicinal plants are recommended for the treatment of snakebites (Alam et al., 2003). In this study we examined the antivenom potential of $A$. paniculata and $A$. indica plant extracts 
against $D$. russelli venom. The neutralization ability of snake antivenoms is still assessed by the traditional in vivo lethality assay (minimum effective dose $E_{50}$ ), comparable to those used for bacterial antitoxins, usually performed in mice

(WHO, 1981). Thus various pharmacological activities like lethality, edema forming activity, hemorrhagic activity, fibrinolytic activity, $\mathrm{PLA}_{2}$, procoagulant activity caused by $D$. russelli venom were carried out. Neutralization of these pharmacological effects was carried out using $A$. paniculata and $A$. indica plant extracts. Neutralization studies can be performed by incubating of venom and plant extracts prior to testing (pre-incubation method). The results showed that the both plant extracts were capable of neutralizing the lethality induced by the venom. The $D$. russelli venom showed the presence of $\mathrm{PLA}_{2}$ enzymes by means of producing hemolytic haloes in indirect hemolytic assays. Both plant extracts were capable of inhibiting $\mathrm{PLA}_{2}$ dependent hemolysis of sheep RBCs in a dose dependent manner. Edema-forming activity was assessed for $D$. russelli venom and both plant extracts were found to be effective in neutralization of edema induced by venoms. There was a significant decrease in the edema (footpad thickness) when there was an increase in the antivenom (plant extract) dose. Procoagulant activity induced by $D$. russelli venom was studied using human citrated plasma and $A$. paniculata and $A$. indica plant extracts were found to be effective in the neutralization of procoagulant activity. An. paniculata and $A$. indica plant extracts effectively antagonised the Russell's viper venom-induced defibrinogenating activity and fibrinolytic activity. In conclusion the present experimental results indicate that $A$. paniculata and $A$. indica plant extracts were effective in neutralizing the toxic effects of the $D$. russellivenom.

Table 2. Phospholipase activity of D.russelli venom and its neutralization by plant extracts

\begin{tabular}{|c|c|c|}
\hline Plant extracts & $\begin{array}{c}\text { Dose of } \\
\text { D. russelli } \\
\text { venom }(\mu \mathrm{g})\end{array}$ & $\begin{array}{c}\text { Neutralization of venom } \\
\text { by plant extracts } \\
\left(E_{50} \text { in } \mathrm{mg}\right)\end{array}$ \\
\hline A. paniculata & $10(1 \mathrm{Unit})$ & $0.13 \mathrm{mg}$ \\
\hline A. indica & $10(1$ Unit) & $0.11 \mathrm{mg}$ \\
\hline
\end{tabular}

\section{Reference}

1. Alam MI and Gomes A (2003) Snake venom neutralization by Indian medicinal plants (Vitex negundo and Emblica officinalis) root extracts. J. Ethnopharmacol. 86, 75-80.

2. Bawaskar HS (2004) Snake venoms and antivenoms: critical supply issues. J. Asso. of Physns. India. 52, 11-13.

3. Camey Kyoko U., David T. Velarde and Eladio F. Sanchez (2002) Pharmacological characterization and neutralization of the venom used in the production of Bothropic antivenom in Brazil. Toxicon. 40, 501-509.

4. Chippaux JP (1998) Snake-bites: appraisal of the global situation. Bull WHO. 76, 515-524.

5. Ermila Rojas, Lil Quesada, Viviana Arce, Bruno Lomonte, Gustavo Rojas and Jose Maria Gutierrez (2005) Neutralization of four Peruvian Bothrops sp. snake venoms by polyvalent antivenoms produced in Peru and Costa Rica: preclinical assessment. Acta Tropica. 93, 85-95.
Vol.2 No 4 (Mar. 2009)

ISSN: 0974- 6846

6. Gutierrez JM, Avila C, Rojas E and Cerdas L (1988) An alternative in vitro method for testing the potency of the polyvalent antivenom produced in Costa Rica. Toxicon. 26, 411- 413

7. Laing GD, Theakston RDG, Leite RP, Dias Da Silva WD and Warrell DA (1992) Comparison of the potency of three Brazilian Bothrops antivenoms using in-vivo rodent and invitro assays. Toxicon. 30 (10), 1219-1225.

8. Lomonte B, Tarkowski A, Hanson HA (1993) Host response to Bothrops asper snake venom: analysis of edema formation, inflammatory cells, and cytokine release in mouse model. Inflammation. 17, 95-105.

9. Manoj Lakhotia, Dinesh Kothari, Dharma Ram Choudhary, Sanjeev Sharma and Pravesh Jain (2002) A case of saw scale viper snakebite presenting as pleuro-pericardial haemorrhage. JIACM. 3(4), 392-394.

10. Maya Devi C, Vasantha Bai Mary, Vijayan Lal Arthur, Umashankar PR and Krishnan Lissy K (2002) An improved method for isolation of antiviper venom antibodies from chicken egg yolk. J. Biochem. Biophys. Methods. 51, 129138.

11. Rojas, G., Guturrez, J.M., Gene, J.M., Gomez, M., Cerdas, L. (1987). Neutralization de las actividades toxicas $Y$ enzimaticas de cuatro venenos de rerpipentes de Guatemala $\mathrm{Y}$ Honduras por el antivenenopolivalente producido en Costa Rica. Revista de Biologia Tropical. 35, 59-67.

12. Sakda Daduang, Nison Sattayasai, Jintana Sattayasai, Pattara Tophrom, Achra Thammathaworn, Arunrat Chaveerach and Monruedee Konkchaiyaphum (2005) Screening of plants containing Naja naja siamensis cobra venom inhibitory activity using modified ELISA technique. Anal. Biochem. 341, 316-325.

13. Santosh R, Fattepur and Shivaji P Gawade (2004) Preliminary screening of herbal plant extracts for antivenom activity against common sea snake (Enhydrina schistosa) Poisoning. Pharmacog. Magazine. 16, 56-60.

14. Sharma Sanjib K, Chappiux Francois, Arjha Nalhamb, Patrick A, Loutan Louis and Koirala Shekhar (2004) Impact of snake bites and determinants of fatal outcomes in southeastern Nepal. Am.J.Trop.Med.Hyg. 71 (2), 234-238.

15. Theakston RDG and Reid HA (1983) Development of simple standard assay procedures for the characterization of snake venoms. Bull. World Health Org. 61, 949-956.

16. Ticli FK, Hage LI, Cambraia RS, Pereira PS, Magro AJ, Fontes MR, Stábeli RG, Giglio JR, França SC, Soares AM and Sampaio SV (2005) Rosmarinic acid, a new snake venom phospholipase A2 inhibitor from Cordia verbenacea (Boraginaceae): antiserum action potentiation and molecular interaction. Toxicon. 46 (3), 318-327.

17. World Health Organization (1981) Progress in characterization of venoms and standardization of antivenoms. WHO offset publication number.58, Geneva.

18. Yamakawa M, Nozaky M and Hokama Z (1976) Fractionation of sakishimahabu (Trimeresurus elegans) venom and lethal, hemorrhagic and edema-forming activities of the fractions. In: Toxins: Animal, Plant and Microbial. Eds. Ohsaka A, Hayashi K \& Sawai Y, New York. Plenum Press. pp: 97-109.

19. Yao-Ching Hung, Vasyl Sava, Meng-Yen Hong and Steven Huang G (2004) Inhibitory effects on phospholipase A2 and antivenin activity of melanin extracted from Thea sinensis Linn. Life Sci. 74, 2037-2047.
Research article

CIndian Society for Education and Environment (iSee)
"Plant extracts as antivenom" http://www.indjst.org
Meenatchisundaram et al. Indian J.Sci.Technol. 